\title{
Development of Acta Informatica Pragensia Journal and Acknowledgement to Reviewers
}

\author{
Stanislava Mildeová ${ }^{1}$, Zdeněk Smutný ${ }^{2}$, Michal Doležel ${ }^{3}$
}

\begin{abstract}
The article summarizes the development of Acta Informatica Pragensia journal which focuses on social and business aspects of informatics. The journal has built an important position in the past six years among informatics-oriented journals in the Czech Republic and in the Slovak Republic. To even strengthen this position, structural changes were made and the mission of the journal was reformulated, emphasizing the importance of informatics-related issues connected with the Central and Eastern European region. The need for such a journal in this region is discussed in detail, with reference to the different methodological approaches used in informatics that are historically associated with the former Western and Eastern Bloc. The article also introduces current members of the editorial board, the abstracting and indexing services in which the journal is registered, and includes an acknowledgement to reviewers.
\end{abstract}

Keywords: Acta Informatica Pragensia, Editorial board, Editorial material, Reviewers.

\section{Development of Acta Informatica Pragensia Journal}

Acta Informatica Pragensia journal has been in existence for six years. As editors of this journal, we would like to summarize in this paper the development of this journal during this period and present its further development. The Acta Informatica Pragensia journal was established in 2012 at the University of Economics, Prague as a platform for publishing scholar articles in the field of applied informatics, including its inter- and transdisciplinary character, with an emphasis on the issue of its management and government in socio-economic environment. The name of the journal follows another journal that the University of Economics, Prague has been publishing for two decades in business and management area - Acta Oeconomica Pragensia.

The purpose of establishing the Acta Informatica Pragensia journal was to contribute to the development of a field that lies, in the Czech and the Slovak Republic, at the boundary of informatics, management and economics. There were very few high-quality publication platforms for this field of study in this region, and scholars and academics thus had to publish

\footnotetext{
${ }^{1}$ Department of Computer Science and Mathematics, Faculty of Economic Studies,

University of Finance and Administration, Estonská 500, 10100 Prague 10, Czech Republic

$\triangle$ mildeova@vsfs.cz

2 Department of Systems Analysis, Faculty of Informatics and Statistics, University of Economics, Prague,

W. Churchill Sq. 1938/4, 13067 Prague, Czech Republic

${ }^{3}$ Department of Information Technologies, Faculty of Informatics and Statistics, University of Economics, Prague,

W. Churchill Sq. 1938/4, 13067 Prague, Czech Republic
} 
in journals focusing either on informatics (more technologically oriented) or on economics and management (more oriented on business or economic issues). This journal was to offer them a solution for this dilemma.

Another important reason for establishing the journal was the endeavour to contribute to increasing the culture of $\mathrm{PhD}$ students' publications by providing valuable feedback to the manuscripts they send. Initially, the journal was thus designed as a regional medium that encourages scholarly communication and cooperation between universities. Among the main areas of interest were: business informatics, information management, knowledge engineering, systems science, trans- and interdisciplinarity in informatics.

In 2012-2017, 92 original articles were published that had undergone the peer-review process, as well as 19 articles that had not been reviewed (book reviews, interviews, conference reports, reflections). One article was retracted after its publication due to a serious violation of author ethics. Participating in the assessment of received manuscripts in the review process in this period were members of the Editorial Board, along with 86 external reviewers - see Sections 1.2 and 2.

During its existence, Acta Informatica Pragensia has undergone a number of changes in the focus of the journal, its management, as well as within the Editorial Board. A very significant change is the modification of the journal's aims and scope in connection with its new orientation on the region of Central and Eastern Europe. The journal's position in the region has been strengthened mainly by an effort to internationalize both the Editorial Board and contributors by the use of promotional activities in the region. The journal explicitly emphasizes a thematic orientation on social and business aspects of informatics.

The journal's ambition is to stimulate the dialogue concerning the role of ICT in the region of Central and Eastern Europe. This geographical area is affected by two main factors: the recent history of the Eastern Bloc, and the pro-Western development in the past few decades. This situation is also reflected in the paradigms of informatics research in the region, e.g. in the strong tradition of informatics research based in cybernetics and other system-oriented disciplines, but also in the effort to create a close connection between research and practice. In contrast with that, there is a growing awareness in the region of the "Western tradition" of informatics research. This means mainly the social research focused on such ICT topics as the behavioural tradition of the study of information systems in organizations.

The journal should contribute to the building of a new tradition in the Eastern region based on social and behavioural research in the field of informatics, and thereby pay a certain debt made by previous generations of academics, as this area did not receive appropriate attention under past social conditions, which also affected academic communities. The journal should also contribute to the development and promotion of design science research, which replaces or mixes with system-oriented approaches to artifact design. Despite the above, it would be appropriate to keep a trace of the formerly applied research approaches and perspectives for future generations.

There have also been changes in the structure of the Editorial Board. Since 2018 it has been divided into five thematic sections (Information Systems Development, Knowledge Technology and the WWW, Public Administration Informatics, Social Informatics, Systems Engineering), managed by Section Editors-in-Chief. These sections reflect the focus of the journal on social and business aspects of informatics and enable a more flexible review process, as well as splitting the work between several Editorial Board members. There have also been changes in the position of Managing Editor, which was held from 2012 by Zdeněk Smutný and Václav Řezníček. At the end of 2016, Václav Řezníček terminated his work in this position, 
which was then taken over by Michal Doležel in the middle of 2017. Newly contributing to the publication of the journal are, alongside University of Economics, Prague (publisher), the journal's two university partners, each managing their own thematic sections: University of Pardubice, and University of Finance and Administration.

Great emphasis has been put on improving the quality of the review process, thereby improving the feedback given to authors. This, in turn, increases the quality of manuscripts received in the individual stages of the review process. The journal also supports young researches and $\mathrm{PhD}$ students, who can receive constructive critical reviews by renowned reviewers. Since mid-2014, the journal has used anti-plagiarism software in Czech and Slovak (Odevzdej.cz) and since 2016 also in the English language (iThenticate).

Acta Informatica Pragensia journal has been included in a number of abstracting and indexing services or databases - see Section 1.1. These databases are focused mainly on literature from the Central and Eastern European region, e.g. Central and Eastern European Online Library, Russian Science Citation Index. The editors hope that in the years to come the journal will contribute more to international discourse in the field of informatics with an emphasis on issues connected with Central and Eastern Europe region.

In conclusion, we would like to thank the people who supported our endeavour in its beginnings and shared their advice and experience, Ján Pavlík and Miroslav Vacura (E-LOGOS Electronic Journal for Philosophy) to name but a few. We would also like to thank the management of Faculty of Informatics and Statistics, University of Economics, Prague and the editors from other university journals who have shared their experience with publishing a peer-reviewed journal, namely Jiřina Bulisová (Politická ekonomie), Klára Pavlová (Prague Economic Papers), Jindřich Špička (Acta Oeconomica Pragensia), and Ondřej Machek (Central European Business Review). A big thank you also belongs to Ivo Andrle from Solen Software for his improvements of the review management and the editorial system Actavia to suit the journal's needs.

\subsection{Journal Abstracting and Indexing}

The journal Acta Informatica Pragensia is included in the Government List of Peer-Reviewed Journals Published in the Czech Republic approved by the Government Office for Science, Research and Innovations of the Czech Republic. Articles published in the journal are freely available in a number of national and university libraries around the world (e.g. National Library of Australia, Georgetown University Library, Iowa State University Library). The journal Acta Informatica Pragensia is covered by the following main databases and archives:

- Baidu Scholar

- BASE - Bielefeld Academic Search Engine

- CEEOL - Central and Eastern European Online Library

- DOAJ - Directory of Open Access Journals

- Directory of Open Access Scholarly Resources (ROAD - ISSN International Centre)

- Crossref Metadata - DOI prefix 10.18267

- EconPapers (RePEc)

- EZB - Electronic Journals Library / Elektronische Zeitschriftenbibliothek

- ERIH PLUS - European Reference Index for the Humanities and the Social Sciences

- Genamics JournalSeek

- Google Scholar

- IDEAS (RePEc)

- National Library of the Czech Republic 
- OCLC WorldCat

- Open Archives Initiative

- Pablikado - Online publishing system of professional literature

- $\quad$ RSCI - Russian Science Citation Index (eLibrary.ru)

- Wilbert (Wildauer Bücher + E-Medien Recherche-Tool)

\subsection{Editorial Board as of June 2018}

The Editorial Board of the journal Acta Informatica Pragensia has an international profile from the beginning and is formed by major academics from various universities and professionals from practice. The journal has five main sections, each with its own Section Editor-in-Chief. The publisher would like to express thanks to the following members of the Editorial Board for their work.

\section{Editor-in-Chief}

Stanislava Mildeová

University of Finance and Administration, Czech Republic

\section{Section Board for Information Systems Development}

Michal Doležel

Section Editor-in-Chief, University of Economics, Prague, Czech Republic

Klára Antlová, Technical University of Liberec, Czech Republic

Tomáš Bruckner, University of Economics, Prague, Czech Republic

Alena Buchalcevová, University of Economics, Prague, Czech Republic

Jiří Fišer, Jan Evangelista Purkyne University in Usti nad Labem, Czech Republic

Jan Ministr, VSB-Technical University of Ostrava, Czech Republic

Stanisław Wrycza, University of Gdańsk, Poland

\section{Section Board for Knowledge technology and the WWW}

Ondřej Zamazal

Section Editor-in-Chief, University of Economics, Prague, Czech Republic

Jérôme David, Université Grenoble Alpes, INRIA, France

Vít Nováček, NUI Galway, Ireland

Jan Rauch, University of Economics, Prague, Czech Republic

Vojtěch Svátek, University of Economics, Prague, Czech Republic

Olga Štěpánková, Czech Technical University in Prague, Czech Republic

Esko Turunen, Tampere University of Technology, Finland 
Zdeněk Zdráhal, The Open University, United Kingdom

\section{Section Board for Public Administration Informatics}

Miloslav Hub

Section Editor-in-Chief, University of Pardubice, Czech Republic

Martin Boháček, University of Economics, Prague, Czech Republic

Rasa Daugèlienè, Kaunas University of Technology, Lithuania

Petr Hájek, University of Pardubice, Czech Republic

Petr Kučera, Power Patterns, Prague, Czech Republic

Monika Mačiulienè, Mykolas Romeris University, Lithuania

Eve Mitleton-Kelly, University of London, United Kingdom

Michal Munk, Constantine the Philosopher University in Nitra, Slovakia

Antonín Slabý, University of Hradec Kralove, Czech Republic

\section{Section Board for Social Informatics}

Zdeněk Smutný

Section Editor-in-Chief, University of Economics, Prague, Czech Republic

Jan Lánský, University of Finance and Administration, Czech Republic

Václav Řezníček, Codethica, Ceske Budejovice, Czech Republic

Aelita Skaržauskienè, Mykolas Romeris University, Lithuania

Sakari Taipale, University of Jyväskylä, Finland

Milan Turčáni, Constantine the Philosopher University in Nitra, Slovakia

Sara Vannini, University of Washington, USA

Vasja Vehovar, University of Ljubljana, Slovenia

Taro Yabuki, Chiba Institute of Technology, Japan

Cyril Závadský, University of Economics in Bratislava, Slovakia

\section{Section Board for Systems Engineering}

Stanislava Mildeová

Section Editor-in-Chief, University of Finance and Administration, Czech Republic

Vesna Čančer, University of Maribor, Slovenia

Milan Houška, Czech University of Life Sciences Prague, Czech Republic 
Ingeborg Němcová, University of Economics, Prague, Czech Republic

Markus Schwaninger, University of St. Gallen, Switzerland

Viktor Vojtko, University of South Bohemia in Ceske Budejovice, Czech Republic

Jan Voráček, College of Polytechnics Jihlava, Czech Republic

\section{Past Editorial Board Members (2012-2015)}

Prokop Toman, Czech University of Life Sciences, Prague, Czech Republic

Petr Máša, Partners Financial Services, Prague, Czech Republic

\section{Acknowledgment to Reviewers (2012-2017)}

Each manuscript that is considered for publication as Original Article is reviewed in double blind peer review process by at least two independent reviewers. One reviewer should be the Editorial Board member and the second has to be outside of the Editorial Board. The editors would like to express their sincere gratitude to the following reviewers outside of the Editorial Board for their time and dedication:

\begin{tabular}{ll} 
Babič, František & Janíček, Přemysl \\
Balata, Jan & Janošćík, Václav \\
Baláž, Anton & Jašek, Pavel \\
Bartoška, Jan & Jedlinský, Jakub \\
Bílková, Diana & Kalina, Jaroslav \\
Bojanovský, Jan & Katolický, Arnošt \\
Brožová, Helena & Kedaj, Petr \\
Buchalcevová, Alena * & Klán, Petr \\
Buzek, Jiří & Klíma, Tomáš \\
Čermák, Radim & Klimánek, David \\
Dalihod, Martin & Kný, Milan \\
Dlouhý, Martin & Komínková Oplatková, Zuzana \\
Dömeová, Ludmila & Král, Miroslav \\
Halbich, Čestmír & Kubera, Petr \\
Horný, Stanislav & Lacko, Branislav \\
Hronza, Radek & Lánský, Jan * \\
Hudec, Milan & Lidinský, Vít \\
Ivánek, Jiří & Klvaňa, Jaroslav \\
Jakab, František & Luc, Ladislav \\
\hline
\end{tabular}




\begin{tabular}{ll} 
Madoš, Branislav & Svatoš, Oleg \\
Maturová, Doris & Šauer, Petr \\
Matuštík, Ondřej & Šperková, Lucie \\
Měsíček, Libor & Št’astná, Jana \\
Milde, Daniel & Šulc, Zdeněk \\
Musil, Petr & Švasta, Jaroslav \\
Náplava, Pavel & Šviráková, Eva \\
Neumaierová, Inka & Tichá, Lucie \\
Nulíček, Vladimír & Tomášek, Jiří \\
Palovský, Radomír & Tomášek, Martin \\
Pásler, Miroslav & Trejbal, Pavel \\
Pavlíček, Antonín & Tvrdíková, Milena \\
Peterka, Jiří & Tvrzský, Tomáš \\
Pícka, Marek & Tyrychtr, Jan \\
Polák, František & Urban, Ondřej \\
Pospíšilová, Irena & Valky, Gabriel \\
Procházka, Jaroslav & Veber, Jaromír \\
Rabe, Vlasta & Vencovský, Filip \\
Rosický, Antonín & Vlčková, Veronika \\
Rozehnal, Petr & Vlček, Václav \\
Schlossberger, Otakar & Vojíř, Stanislav \\
Sigmund, Tomáš & Vondra, Zdeněk \\
Solodujev, Miroslav & Zamazal, Ondřej * \\
Sudzina, František & Zumr, Jiříi \\
\hline &
\end{tabular}

* At the time of writing review report, these scholars were not members of the journal Editorial Board.

Copyright @ 2018 by the author(s). Licensee University of Economics, Prague, Czech Republic. This article is an open access article distributed under the terms and conditions of the Creative Commons Attribution License (CC BY), which permits use, distribution and reproduction in any medium, provided the original publication is properly cited, see http://creativecommons.org/licenses/by/4.0/. No use, distribution or reproduction is permitted which does not comply with these terms.

Editorial material I Published: 30 June 2018 
